\title{
SEQUENCE STRATIGRAPHY OF THE EOCENE ROCKS IN QATAR PENINSULA, ARABIAN GULF
}

\author{
Al-Saad, H. A. ${ }^{1}$ and Hewaidy, A. A. ${ }^{2}$ \\ 1- Environmental Science Center, Qatar University, P. O. Box 2713, Doha, Qatar. \\ 2- Geology Department, Faculty of Science, Al- Azhar University, P. O. Box 11884, Cairo, Egypt.
}

\begin{abstract}
The Eocene sedimentary succession of Qatar is subdivided, from older to younger, into the Umm er Radhuma, Rus and Dammam formations. This Eocene succession forms a part of the Arabian Plate Megasequence (AP10) and has been partitioned into two sequences; Pg 10 and Pg 20 respectively. The lithofacies and biofacies studies of this Eocene megasequence in Qatar have enabled the identification and interpretation of the depositional settings and faunal elements of the different Eocene units. The lower Pg 10 sequence is represented by the shallow water Umm Er Radhuma and Rus formations, and is subdivided into a lower transgressive and an upper highstand systems tracts, while the upper Pg 20 sequence is represented by the shallow water Dammam Formation, and is subdivided into a transgressive and a highstand systems tracts. These two sequences are bounded by three major sequence boundaries.
\end{abstract}

Keywords: Eocene; Sequence stratigraphy; Biofacies; Lithofacies; Qatar, Arabian Gulf.

\section{INTRODUCTION}

The Eocene sedimentary rocks cover more than $85 \%$ of the surface area and much of the subsurface section of of Qatar peninsula (Fig. 1). The Eocene rocks of Qatar fall within the Hasa Group which is subdivided, from older to younger, into the Umm Er Radhuma, Rus and Dammam formations. The Umm Er Radhuma and the lower major part of the Rus formations are penetrated by subsurface wells, while the upper part of the Rus and the Dammam formations are exposed on the surface. The limestones and dolomites of the Umm Bab Member of the Dammam Formation and the upper part of the Rus Formation, cover most of the peninsula.

From the perspective of biostratigraphy the Paleogene foraminifera form the first and most studied group of fauna of Qatar. It was first examined in the pioneer study of Smout (1954). Cavelier (1970) established the basic framework for the surface Qatar stratigraphy. Since then many contributions to the stratigraphy and paleontology have been added by Casier (1971), Blondeau and Cavelier (1975), Roman (1976), Abu-Zeid and Boukhary (1984), Boukhary (1985), Abu-Zeid (1991), Hewaidy and Al-Saad (1993), Hewaidy (1994), Hewaidy and Al- Hitmi, (1994), Boukhary and Alsharhan (1998), Hewaidy and Al- Hitmi (1999) and Boukhary et al. (2011). Studies of the lithofacies and biofacies characteristics of the Eocene rocks of Qatar have been supported by the basic sequence stratigraphy of the Phanerozoic succession of the Arabian Peninsula established by Sharland et al. 2001. Previously no works have been published on the Eocene succession of Qatar.

The main purpose of this study is to combine a review of the rock units of the Eocene successions with a sequence stratigraphic classification of the Paleogene rocks of Qatar. This is based on paleontologic and lithologic analyses made to these rocks from five oil wells drilled in the Dukhan Oil Field (A-E) (356 core and ditch samples) and one water well (A4) near Traina in southern Qatar (77 cutting samples). In addition, 107 rock samples were collected from six surface sections measured in the G. Dukhan (section 1) and the Umm Bab (section 2) of western Qatar, the Qarn El-Mazroua (section 3) of central Qatar and the Al-Khor (section 4), the Zakheira (section 5) and the North Zakheira (section 6) of northeast Qatar (Fig. 1). The foraminifera and mega-fossil contents of the different Eocene units in these sections were examined and the distribution of all the identified faunal elements in different Eocene rock units has been 
Al-Saad, H. A. and Hewaidy, A. A.

shown on (Figs. 2-6). Ninety-five thin sections were prepared to study the microfacies and biofacies characteristics of these rocks (Plates 1-3).

Fig. 1: Location map showing the studied sections, structures and exposed rocks in Qatar.

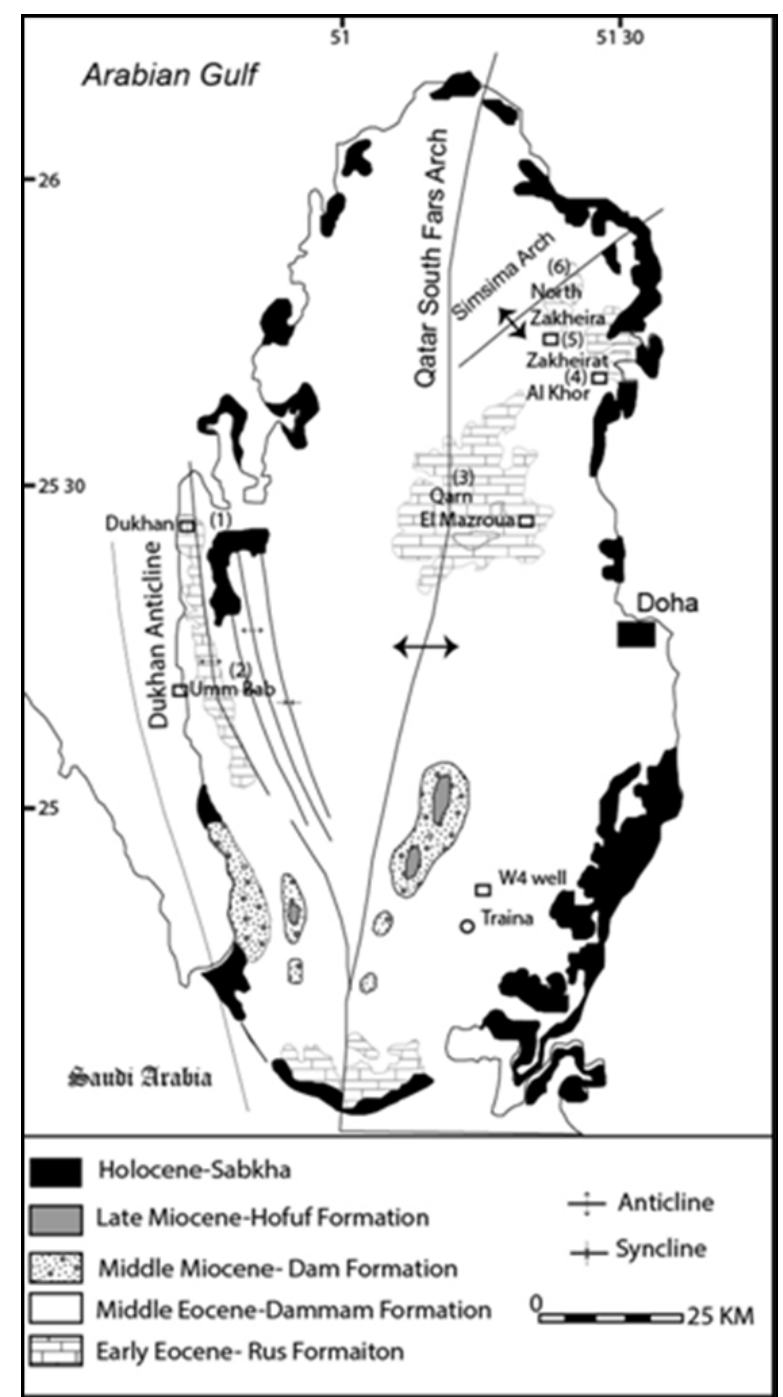

\section{STRATIGRAPHIC UNITS}

The distribution of the sedimentary facies of the Eocene rocks in Qatar was controlled by a regional gentle anticline (Qatar Arch) together with small gentle longitudinal folds that include the Dukhan anticline and the Simsima dome (Fig. 1). These structural elements are interpreted to represent the northeastern extension of the central Arabian Arch (Sugden, 1962).

The Paleogene sediments of Qatar and east Arabia form the Hasa Group which, from older to younger, has been subdivided into the Umm Er Radhuma, Rus and Dammam formations (Fig. 2). Cited in Nairn and Alsharhan (1997) these rocks were originally termed the "Bahrain Series" by Pilgrim (1908) and subsequently renamed the Hasa Group (or Series) from outcrops in Saudi Arabia by Sander (1962). They were then raised to a group by Owen and Nasr (1958). The absence of marker fossils in the major part of these Paleogene sediments of Qatar and east Arabia makes detailed age attribution controversial.

\section{The Umm Er Radhuma Formation}

The Umm Er Radhuma Formation was named by Henry \& Brown, 1935 from sections in the Umm er Radmah wells (lat. $28^{\circ} 41^{\prime}$ N., long. $44^{\circ} 41^{\prime}$ E.). The Umm Er Radhuma Formation was first cited in a 


\section{Sequence Stratigraphy of the Eocene rocks in Qatar Peninsula}

publication by Steineke and Bramkamp (1952). Powers et al. (1966) and Powers (1968) described the Umm Er Radhuma Formation as a repetitious series of light-colored foraminiferal aphanitic and calcarenitic limestone, dolomitic limestone and dolomite. In the reference section, the top part of the formation is not exposed but it is present in water wells where the Umm Er Radhuma dolomite containing Lockhartia hunti Ovey pustulosa Smout is overlain by the soft chalky limestones of the Rus Formation with an interpreted but subtle unconformity. The thickness at the reference section is about $243 \mathrm{~m}$.

In Qatar, the reference section of the Umm Er Radhuma Formation was chosen by Sugden and Standring (1975) from the Qatar Petroleum Company well no. 22 (lat. $25^{\circ} 22^{\prime} 38^{\prime \prime}$ N., long. 50 48 $34^{\prime \prime}$ E.) in the G. Dukhan structure and subdivided from base to top into 5 informal units (A - E) (Fig. 2). The lower member (A member) is widely distributed over the Arabian plate and is named as the Shammar Shale. Using the larger foraminiferal content, the Umm Er Radhuma Formation was subdivided into 7 biozones, (Smout, 1954). The lower six of these zones were considered of Paleocene age, while the 7th is of Early Eocene age (Powers et al., 1966, Powers, 1968, Cavelier, 1970 and El-Khayal, 1974. Based on pelagic foraminifera contained in unit (B) of the Umm Er Radhuma Formation, the major part of the Umm er Radhuma Formation is attributed to the Lower Eocene (Ypresian) age (Hasson, 1985; Hewaidy, 1994; Boukhary et al., 2006 and Boukhary et al., 2011).

The contact between the Umm Er Radhuma Formation and the underlying Simsima Formation is apparently unconformity relationship. This contact is drawn between the Lockhartia- bearing argillaceous limestone of the base Umm Er Radhuma Formation and the shaly dolomitic limestone with characteristic Maastrichtian fauna at the top of the Simsima Formation where the topmost Maastrichtian as well as the Paleocene and possibly the base of the Lower Eocene (Ypresian) are missing.

The lithologic characteristics of the Umm Er Radhuma Formation of Qatar were studied using cutting samples. The Umm Er Radhuma Formation is subdivided into five informal members (A-E) from older to younger, which are characterized by lithologic continuity throughout Qatar.

The basal Shammar Shale (A) unit in the five Dukhan wells consists of dark blue pyritic shale to calcareous shale in the northern wells (A, B and C), changing to blue gray pyritic marl with thin beds of black carbonaceous matter at the base in the northern wells (D and E). This unit has a sparse foraminiferal content which is recorded in the upper levels of this unit. The Shammar Shale (A) Member is about $13 \mathrm{~m}$ thick in wells A, B and E, while it is about $14 \mathrm{~m}$ thick in well C and about $9 \mathrm{~m}$ thick at well D. In the Traina well, the Shammar Shale is black pyritic shale which is $12 \mathrm{~m}$ thick.

The Shammar Shale is followed in Dukhan Oil Field by the second unit (member B), which is composed of grey argillaceous limestone at the base changed to grey marly limestone in the middle and compact foraminiferal limestone, which is slightly dolomitic at the top. It is rich in Lockhartia spp. It is $7.5 \mathrm{~m}$ thick in well A, $14.8 \mathrm{~m}$ thick in well $\mathrm{B}, 21.8 \mathrm{~m}$ thick in well C, $47 \mathrm{~m}$ thick in well $\mathrm{D}$ and $51.5 \mathrm{~m}$ thick in well E. In the Traina water well, member B is a grey compact argillaceous limestone rich in larger foraminifera and is $66 \mathrm{~m}$ thick.

The third unit ( $\mathrm{C}$ member) in Dukhan Oil Field is composed of grey limestone at the base changed to a light brown dolomite and light grey dolomitic limestone with nodules of white anhydrite at the top. It was not sampled in wells A, B and C, while in well D it is $50 \mathrm{~m}$ thick and $62 \mathrm{~m}$ thick in well E. In the Traina water well, the member $\mathrm{C}$ is richly fossiliferous grey compact limestone with $125 \mathrm{~m}$ thick. In this water well, the members D and E were sampled. Member D is a dark grey, richly fossiliferous, compact limestone of $79 \mathrm{~m}$ thick, while member $\mathrm{E}$ is a white chalky and anhydritic limestone of $41 \mathrm{~m}$ thick.

In the study area, the Umm er Radhuma Formation is conformably overlain by the Rus Formation with a sharp contact located between the white gypsum with chalk intercalation and grey friable porous and very dolomitic limestone. The lower boundary of the Umm er Radhuma Formation with the underlying Simsima Formation is gradational and cuts between the dark grey argillaceous limestone with Omphalocylus macroporus (Lamarck) of the top Salwa Member of the Simsima Formation and the black pyritic shale unit of the base of the Umm er Radhuma Formation which is nearly barren of foraminifera. 
Al-Saad, H. A. and Hewaidy, A. A.

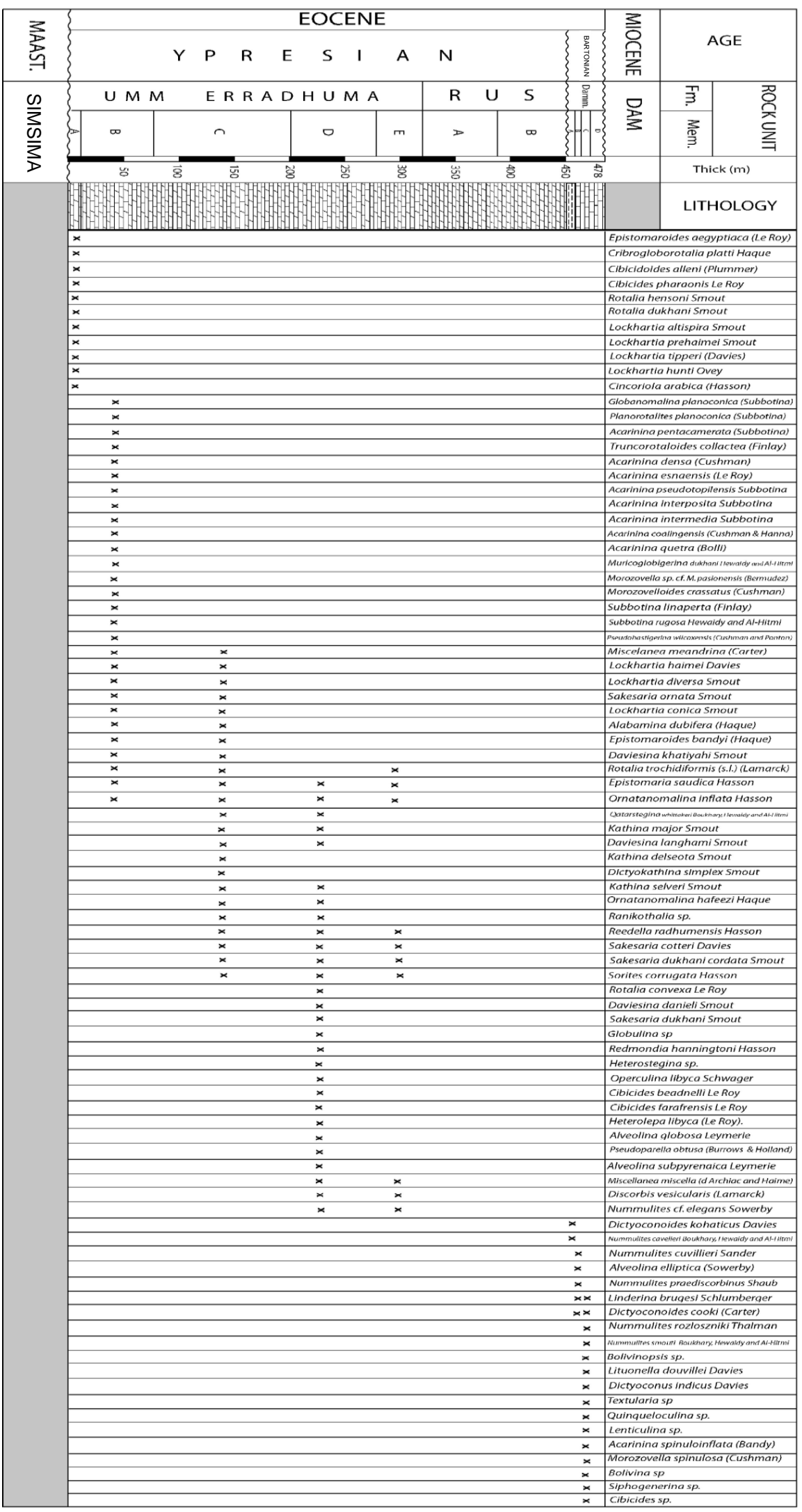

Fig. 2: Distribution chart of the foraminiferal assemblages in different Eocene units in Qatar. 


\section{Sequence Stratigraphy of the Eocene rocks in Qatar Peninsula}

\section{The Rus Formation}

The Rus Formation is named after Umm ar Ru'ūs hill in Saudi Arabia (lat. 26 $16^{\prime}$ N., long. 50 $08^{\prime} \mathrm{E}$.), a small hill where the type section was measured. It was first introduced by Bramkamp, 1946 to replace the old term "Chalky Zone" which had been informally used for the lower Eocene beds above the Umm er Radhuma and below the Dammam Formation by Henry and Hoover, 1934 on the southeastern flank of the Dammam Dome in and below Umm ar Ru'us. The thickness of the Rus Formation at the type section is $56.4 \mathrm{~m}$.

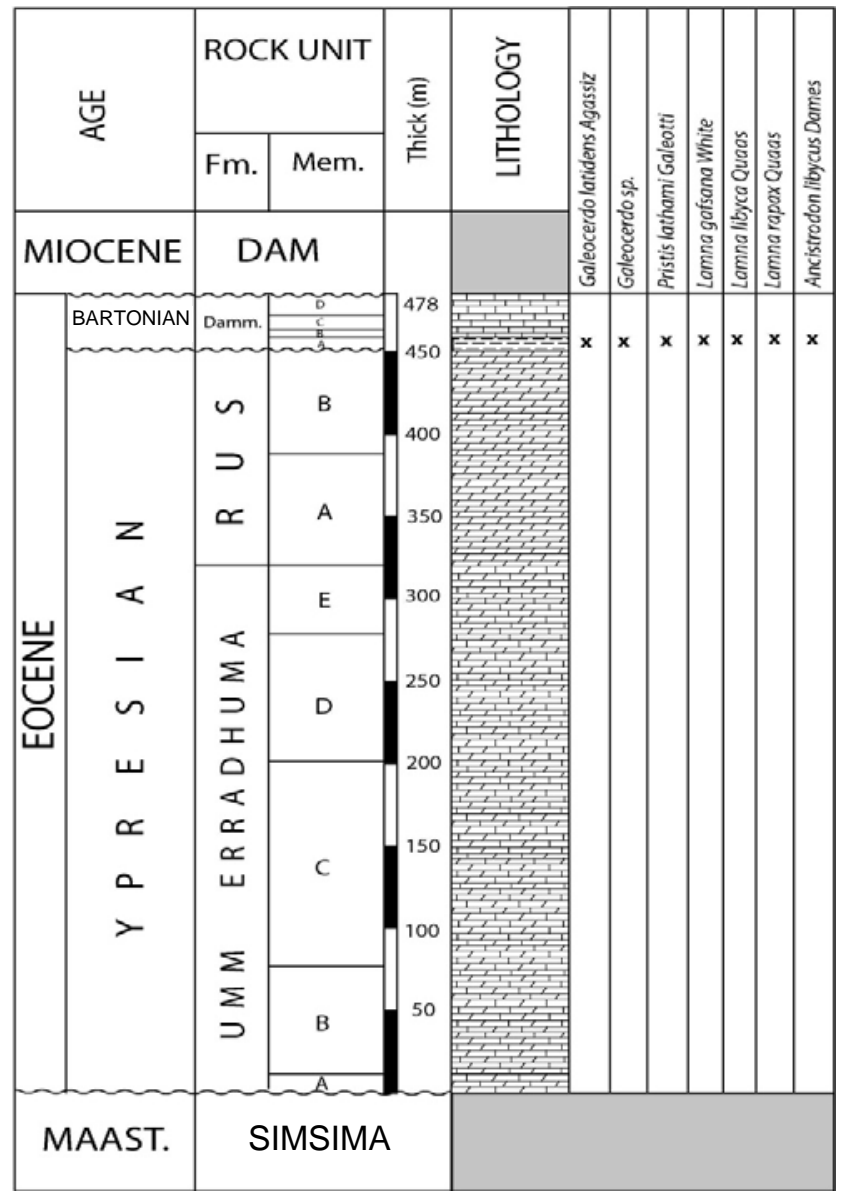

Fig. 3: Distribution chart of the fish remains recorded in the Midra Shale Member, Dammam Formation.

In Qatar, Al-Saad (2003) renamed and subdivided the Rus Formation into two members. The Traina Member, the lower, is composed of gypsiferous dolomitic limestone and the Al-Khor Member, the upper, is composed of chalky limestone. The reference section of the Rus Formation is in G. Dukhan section, where its upper part is outcropping at the foot of this section. The upper boundary of the Rus Formation is located at the change from the light-colored, chalky calcarenite below to yellow-brown shale of the Midra Shale of the Dammam Formation above.

The Rus Formation shows significant lithofacies changes throughout Qatar. The diagenetic history includes strong effect of dolomitization and leaching of dolomites of the Rus Formation. It consists of gypsiferous dolomitic limestone at the lower Traina Member and chalky limestone at the upper Al-Khor Member. The following is the description of the main lithofacies characteristics of the Traina and AlKhobar members of the Rus Formation.

\section{The Traina Member}

The lowermost part of the Traina Member was studied using cutting samples. This member is made up of two main lithofacies: gray to light yellow, hard dolomitic limestone facies and white or silver, thick, 
Al-Saad, H. A. and Hewaidy, A. A.

hard gypsum facies. The dolomitic limestone facies is formed of fine-grained dolomitic rhombs floating in a wackestone/packstone matrix with some gypsum strikes. This lithofacies generally represents the basal part of the gypsum. The thickness of this lithofacies ranges between 3.5 and $4 \mathrm{~m}$.

The gypsum facies is the predominant facies of the Traina Member and is widespread throughout southern Qatar. It is composed of white or silver, thick, hard gypsum intercalated with dolomitic limestone in southern Qatar and with chalky limestone in northern Qatar. The greatest thickness of this lithofacies is recorded in southern Qatar and reaches about $25 \mathrm{~m}$.

Fig. 4: Distribution chart of the bivalves in the Dammam Formation.

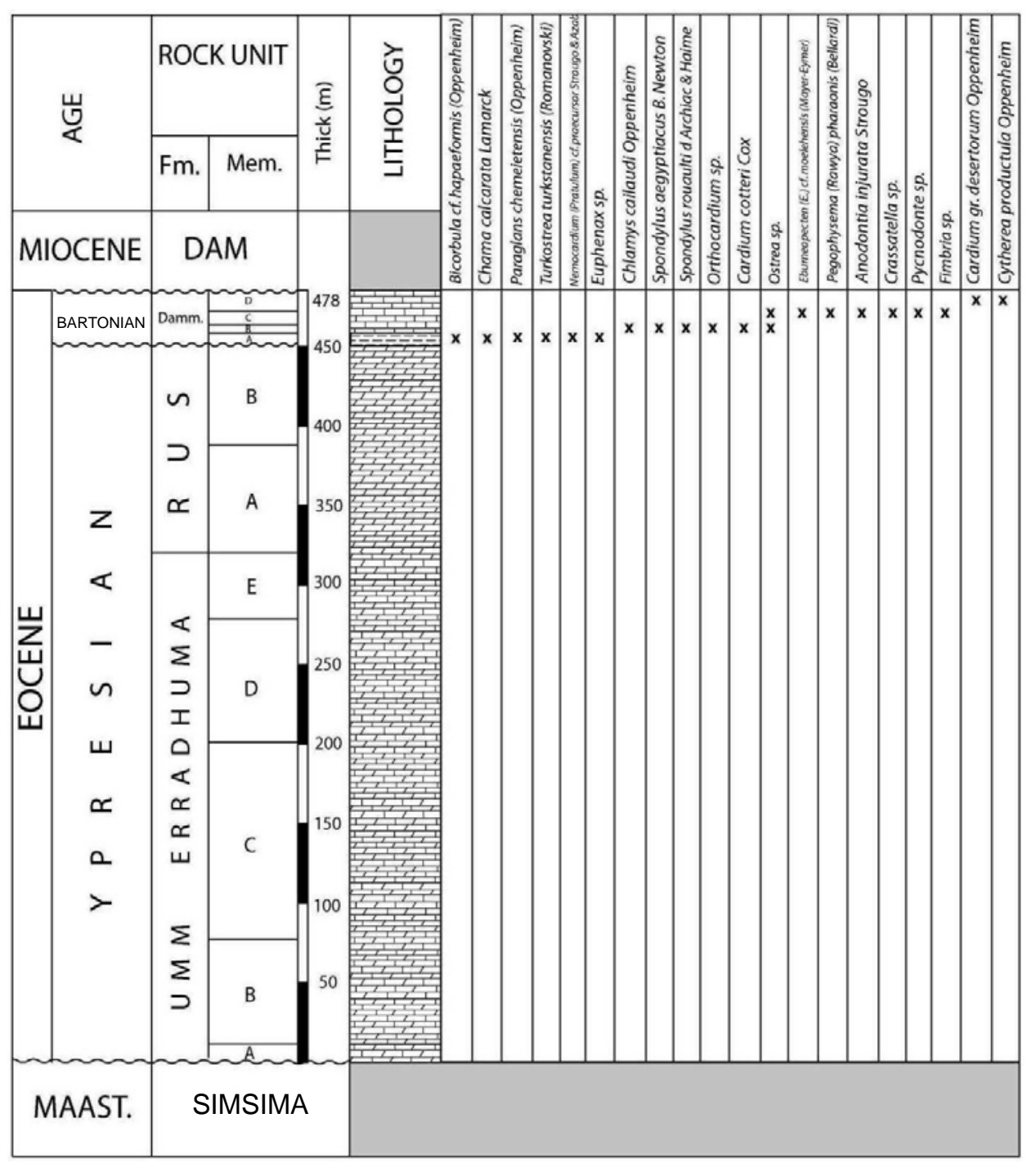

\section{The Al-Khor Member}

This member consists of white to yellow hard fossiliferous limestone in its lower part and light gray, soft, fossiliferous, ferruginous chalky limestone in its middle and upper parts. The limestones represent the major lithofacies of the Al-Khor Member, while very rare horizons of medium to coarse-grained grainstone with dolomite rhombs are encountered in the upper part of the Al-Khor Member. The thickness of this lithofacies ranges between $20 \mathrm{~cm}$. in southern Qatar and $2.5 \mathrm{~m}$ in northern Qatar.

The chalky limestone facies contains some fine quartz grains and gypsum crystals. This lithofacies is rarely encountered in the Traina Member. The thickness of this lithofacies ranges between $2.0 \mathrm{~m}$ and 4.0 m. thin bands, of about $20-35 \mathrm{~cm}$ thick, of grayish ferruginous, calcareous, gypsiferous claystone are 


\section{Sequence Stratigraphy of the Eocene rocks in Qatar Peninsula}

common in the Al-Khor Member. The Rus Formation was considered of Lower Eocene (Ypresian) age by Powers et al. (1966), Powers (1968), Boukhary (1985), Al-Hajari (1987) and Abu-Zeid (1991).

\section{The Dammam Formation}

The Dammam Formation was named after Dammam Dome in Saudi Arabia. Bramkamp, 1941, measured and designated the type locality at lat. $26^{\circ} 19^{\prime} 16^{\prime \prime}$ N., long. $50^{\circ} 04^{\prime} 50^{\prime \prime}$ E.). Where present in full thickness, the Dammam Formation is divided into five members. These are, from older to younger, Midra Shale, Saila Shale, Alveolina Limestone, Khobar and Alat Members. The thickness of the Dammam Formation at its type locality is $32.5 \mathrm{~m}$ (Powers et al., 1966).

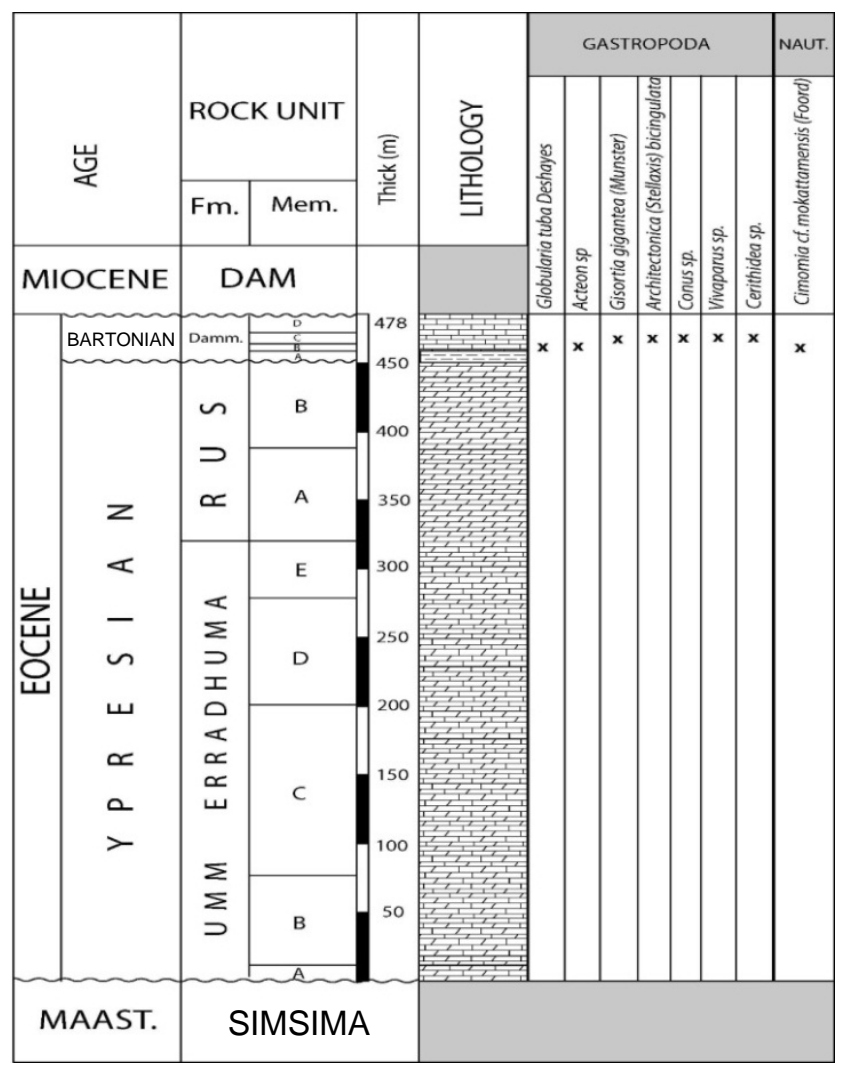

Fig. 5: Distribution chart of the gastropoda and nautiloidea in the Dammam Formation.

In Qatar, the Dammam Formation was used by Cavelier, 1970 with some modifications caused by local lithologic changes. The formation was subdivided into Lower and Upper sub-formations. The Lower Dammam Subformation was subdivided into the Fhaihil Velates Limestone, Midra and Saila Shale and Dukhan Alveolina Limestone members, from older to younger, while the Upper Dammam Subformation was subdivided into Simsima Dolomite and Limestone and Abaruq Dolomitic Limestone and Marl members. Abu-Zeid and Boukhary (1984) included the Fhaihil Member in the Rus Formation and replaced the Simsima with the Umm Bab Member. The reference section of the Dammam Formation of Qatar is in the area between G. Dukhan and the head of Zekrit Bay.

The Dammam Formation in Qatar is subdivided into four formal members arranged from older to younger: Midra Shale, Dukhan, Umm Bab and Abaruq. Qatar is mostly covered by the dolomitic limestones of the Umm Bab Member. The following is a brief description of the different members of the Dammam formation arranged from older to younger:

\section{The Midra Shale}

This member is exposed only in southwestern and central Qatar. In southwestern Qatar, the Midra Shale is composed of soft, gray, light green, fossiliferous, fissile, calcareous, gypsiferous shale incorporated with two beds of marl each ranging in thickness between 0.3 and $0.5 \mathrm{~m}$. In this area, shales 


\section{Al-Saad, H. A. and Hewaidy, A. A.}

accumulated cyclically with marls in a shallow marine setting responding to local Eocene sea-level fluctuations in the region of Qatar caused by local tectonic activation of the Qatar Arch in the southwest and central regions. The shale with marl mixture is interpreted to represent influxes of clastic materials that include shale from nearby land. These facies are laterally changed to clayey facies toward the central region. The thickness of the Midra Shale Member ranges between 2 and $6 \mathrm{~m}$.

In central Qatar, the Midra Shale consists of compact, massive, hard, gray, light green, fossiliferous, partially gypsiferous, calcareous claystone interbedded with two beds of argillaceous limestone at the base and in the middle part. A few thin bands of marl with 2-4 cm thick are intercalated within this facies. Finegrained sandstone and phosphatic concentrations occur. The thickness of this unit ranges between 4 and 9 $\mathrm{m}$. Some beds of Midra Shale have thin parallel lamination and contain ironstone nodules. The base of this member is characterized by the presence of frequent occurrence of shark teeth material, which distinguishes the Dammam Formation from the underlying Rus Formation (Fig. 3).

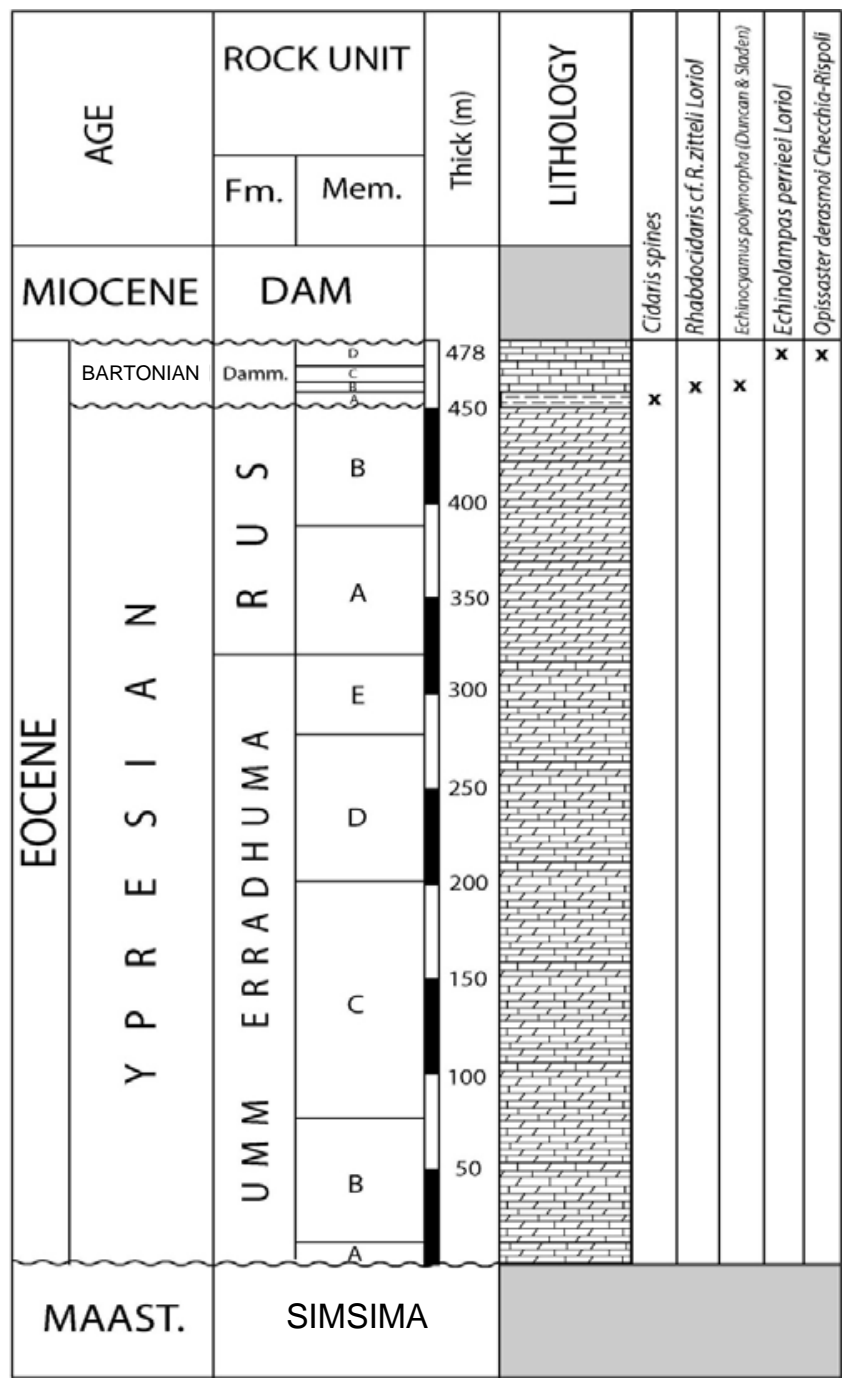

Fig. 6: Distribution chart of the echinoderms in the Dammam Formation.

\section{The Dukhan Member}

This member is also exposed only in southwestern and central parts of Qatar. It is principally composed of massive, nodular gray, light yellow to brown limestone. As a result of a local shallowing, an upward cycle is interpreted. Mudstone facies are common at the base of the member whereas wackestone/packstone textures become abundant towards the top. This unit represents the thinnest rock unit within the Dammam Formation. The thickness of this member ranges between 1 and $3 \mathrm{~m}$. 


\section{Sequence Stratigraphy of the Eocene rocks in Qatar Peninsula}

\section{The Umm Bab Member}

The Umm Bab Member is the most widespread unit in Qatar. This member is mainly composed of hard, massive, light gray, creamy dolomitic cavernous limestone including a very thin marly bed at the base and a thin cherty lens at the top. The thickness varies from 15 to about $30 \mathrm{~m}$.

\section{The Abaruq Member}

This member is composed of a dark yellow, hard, marly limestone at its base that gradually passes upward into light gray massive thin-bedded, partially nodular dolomitic limestone. Most of the dolomites in this member are interpreted to have formed by replacement of a micritic matrix during diagenesis. This unit is recorded only in southwestern Qatar. The thickness of this unit is about $12 \mathrm{~m}$.

The Dammam Formation was attributed to the Ypresian-Lutetian by Willis, (1967), Powers (1968), Cavelier (1970), Sugden and Standring (1975) and Alsharhan and Nairn (1995). Furthermore, it was assigned to the Lutetian age by Hewaidy and Al-Saad (1993). The contact between the Dammam Formation and the overlying Dam (Hadrukh) Formation is disconformaty relationship (Powers, 1968; Sugden and Standring, 1975). This surface is not recorded in Qatar.

The contact of the Dammam Formation with the underlying Rus Formation is apparently conformity relationship on the regional scale (Willis, 1967; Powers, 1968; Cavelier, 1970; Tleel, 1973; Sugden and Standring, 1975; Alsharhan and Nairn, 1995; Sharland et al., 2001). In Qatar, the white to a light gray chalky limestone of the Rus Formation gradually changes upwards to the light yellow or green claystones of the Midra (and Saila) Member of the Dammam Formation. The contact between the Rus and Dammam formations represents the boundary between the Ypresian and Bartonian ages, and is considered to be an unconformity surface (Dill et al. 2003). However, in northeastern Qatar, an abrupt facies change is detected between the Rus and Dammam formations, where the middle member of the Dammam Formation (Umm Bab Member) rests unconformably above the Rus Formation.

In this study, the Dammam Formation is assigned to the Bartonian age. The Midra Shale and Dukhan members are missing in northeastern Qatar. This local diastem is probably related to the activation of paleohighs in the northern part of Qatar, including the Simsima Dome.

\section{BIOFACIES AND PALEOENVIRONMENTS}

The faunal contents of the Eocene rocks of Qatar was previously described in many published works (e.g. Smout, 1954; Cavelier, 1970; Casier, 1971; Blondeau and Cavelier, 1972; Boukhary, 1985; Hewaidy and Al-Saad, 1993; Hewaidy and Al-Hitmi, 1994; Boukhary et al., 1996; Hewaidy and Al-Hitmi, 1999; Al-Saad, 2005 and Boukhary et al., 2011). The environmental interpretation of these faunal assemblages was made by some of these authors. Figure 7 includes the identified faunal elements in different Eocene units of Qatar and the interpreted depositional environments based on various studies.

The Eocene succession of the Qatar Peninsula in marked by its rich content of larger foraminiferal elements of Rotalia, Lockharia, Sakesaria, Kathina, Daviesina Miscellanea, Operculina, Nummulites, Alveolina, Dictyoconus and Qatarstegina. These larger foraminiferal genera were adapted to live in warm, clear, shallow water, within the $25^{\circ} \mathrm{C}$ surface water isotherms and fully marine or slightly hypersaline waters of 35-50 ppm. They are associated with algal symbionts and are thus interpreted to have been restricted to the photic zone.

The Shammar Shale Member at the base the Umm Er Radhuma Formation is marked by lithologic and faunal characteristics of an estuarine setting which is a characteristic of the transgressive systems tract. This unit is composed of black pyritic shale in south west Qatar with very rare faunal elements changed to marl and marly limestones with some Cibicides and rare larger foraminiferal elements of Sakesaria and Lockhartia in the G. Dukhan Field wells. This unit is interpreted to have accumulated in a starved basin setting with slow rates of sedimentation.

The Shammar Shale Member is overlain by a dark grey, compact argillaceous limestone unit with two main assemblages: A planktonic foraminiferal assemblage and a larger foraminiferal assemblage. The 


\section{Al-Saad, H. A. and Hewaidy, A. A.}

planktonic foraminiferal assemblage may be restricted to a thin band in the lower part of this unit just above the Shammar Shale unit. The poor quality of the ditch samples studied have made it is hard to identify this fauna. This planktonic assemblage was detailed studied by Hewaidy and Al-Hitmi (1994) and Boukhary et al. (2011). This assemblage is interpreted to have accumulated in open marine conditions that prevailed during the late Early Eocene time over much of the Arabian Gulf regions. Sediments and faunal characters suggested deepest and most offshore settings for the Eocene time interval over the Arabian Plate coinciding with a Maximum Flooding Surface at the top of a transgressive systems tract and below a high- stand systems tract including the lower members (A and B) of the Umm Er Radhuma Formation.

The overlying members ( $\mathrm{C}, \mathrm{D}$ and $\mathrm{E})$ of the Umm er Radhuma Formation includes rich larger foraminiferal assemblage. This larger foraminiferal assemblage occurs in sediments that were accumulated in marine, shallow water, tropical settings. They are important constituents of coral reef ecological systems and are geographically limited in their distribution within surface water with temperatures interpreted to be greater than $20^{\circ} \mathrm{C}$, shallow shelf areas in the upper part of the photic zone, and to normal salinities (Fig. 7 and Plate 4).

The Rus Formation was found nearly barren of any fauna and have an evaporitic character which may explain the absence of the fauna. It is interpreted to have accumulated where the restricted circulation on the marine platform was affected by the sometimes evaporitic conditions of this setting.

The Dammam Formation is found rich in its macro- and microfossil faunal assemblages. These faunal assemblages are grouped into two assemblages. The first is the fish remains assemblage recorded in the Midra Shale, while the second is the foraminiferal, mollusan and echinoid assemblage recorded in the other overlying carbonate members of the Dammam Formation (Dukhan, Um Bab and Abaruq). The Midra Shale Member includes frequent shark teeth assemblages composed of more than seven species associated with six species of bivalves belonging to the genera Bicorbula, Chama, Paraglans, Turkostrea, Nemocardium and Euphenax, and two larger foraminiferal species of the genera Dictyoconoides and Nummulites, figs. 2-6. These assemblages are interpreted to be lived in a shallow back- bank setting near a terrigenous supply in a tropical climate (fig. 7).

The overlying Dukhan Member is rich in Alveolina, large oysters and Nummulites. Sixteen species are recorded in this member; of which five larger foraminiferal species (two of Nummmulites, one of Alveolina, Linderina and Dictyoconoides), two gastropods (Globularia and Acteon), one nautiloid (Cimomia), six bivalves (two of Spondylus, one of Chlamys, Orthcardium, Cardium and Ostrea). These assemblages of larger foraminifera and the associated elements are interpreted to have accumulated on a very shallow, restricted and protected shelf and reef shoal settings (Fig. 7).

The Umm Bab Member includes a more diverse fauna than the underlying Dukhan and the overlying Abaruq members. Twenty-seven species were recorded in this member. These include fifteen foraminiferal species (most of them were identified in thin sections) (six larger foraminifera of genera Linderina, Dictyoconoides, Nummulites, Daviesiconus and Dictyoconus), seven smaller benthic foraminiferal species and two planktonic foraminiferal species represented very infrequently in the samples; five gastropod species of the genera Gisortia, Conus, Vivaparus and Architectonica, in addition to seven bivalve species of the genera Ostrea, Pycnodonte, Fimbria, Crassatella, Anodontia, Eburneopecten and Pegophysema (Figs. 2-6). This diverse fauna suggest an open, shallow marine platform as compared to the deeper environment rather than the underlying and overlying units of the Dammam Formation (Fig. 7).

The environment becomes shallower progressively during deposition of the overlying Abaruq Member of the Dammam Formation as noted from the complete absence of foraminifera and the very limited number of recorded macrofossil species. Only four species were recorded; two bivalve species of the genera Cardium and Cytherea and two echinoid species of the genera Echinolampus and Opissaster (Figs. 2-6). The Abaruq Member is composed of fine clastics at the base, changing to limestones and dolomites upwards suggesting a progressive shallowing phase upwardly (Fig. 7). 
Sequence Stratigraphy of the Eocene rocks in Qatar Peninsula

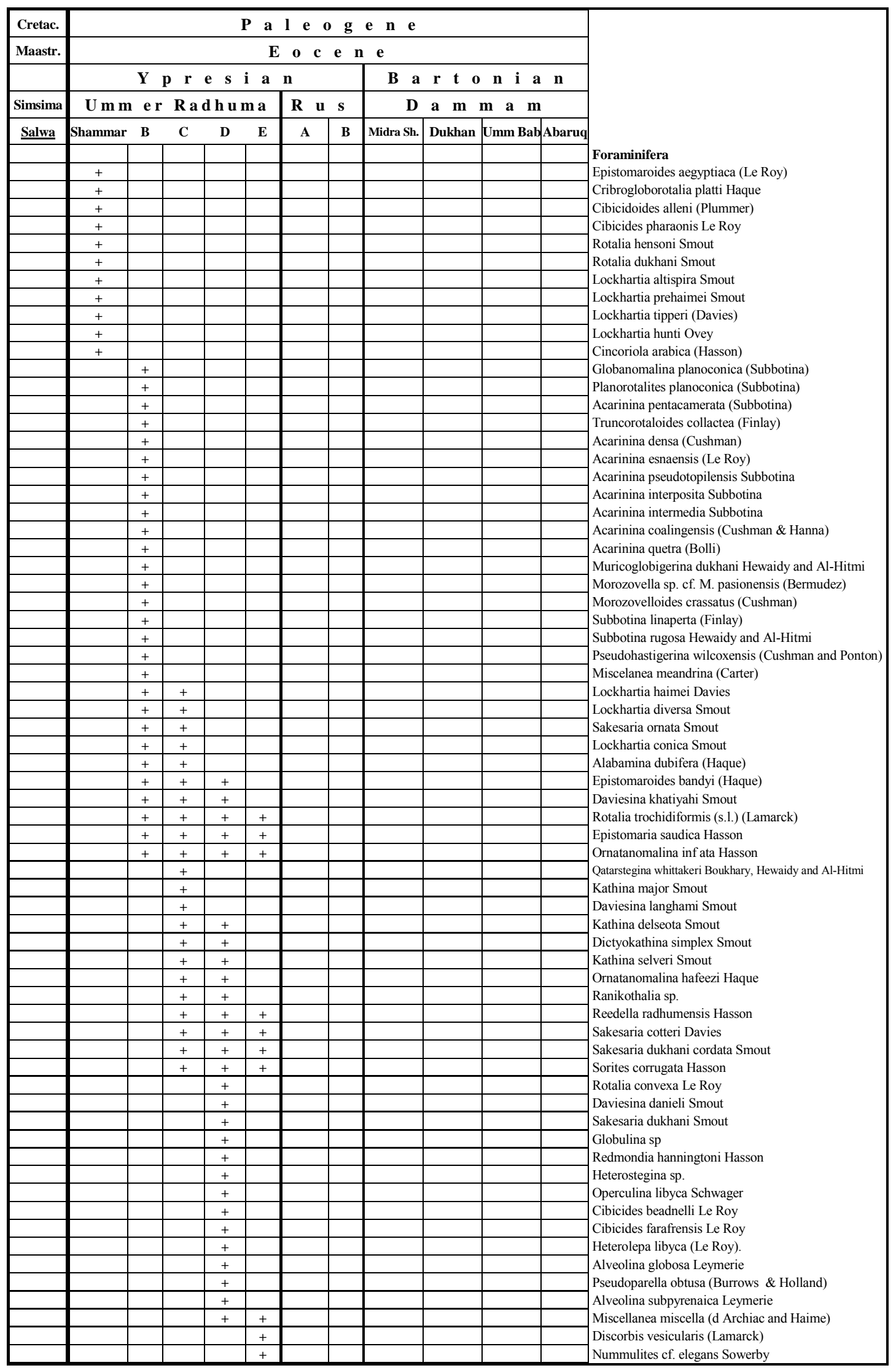


Al-Saad, H. A. and Hewaidy, A. A.

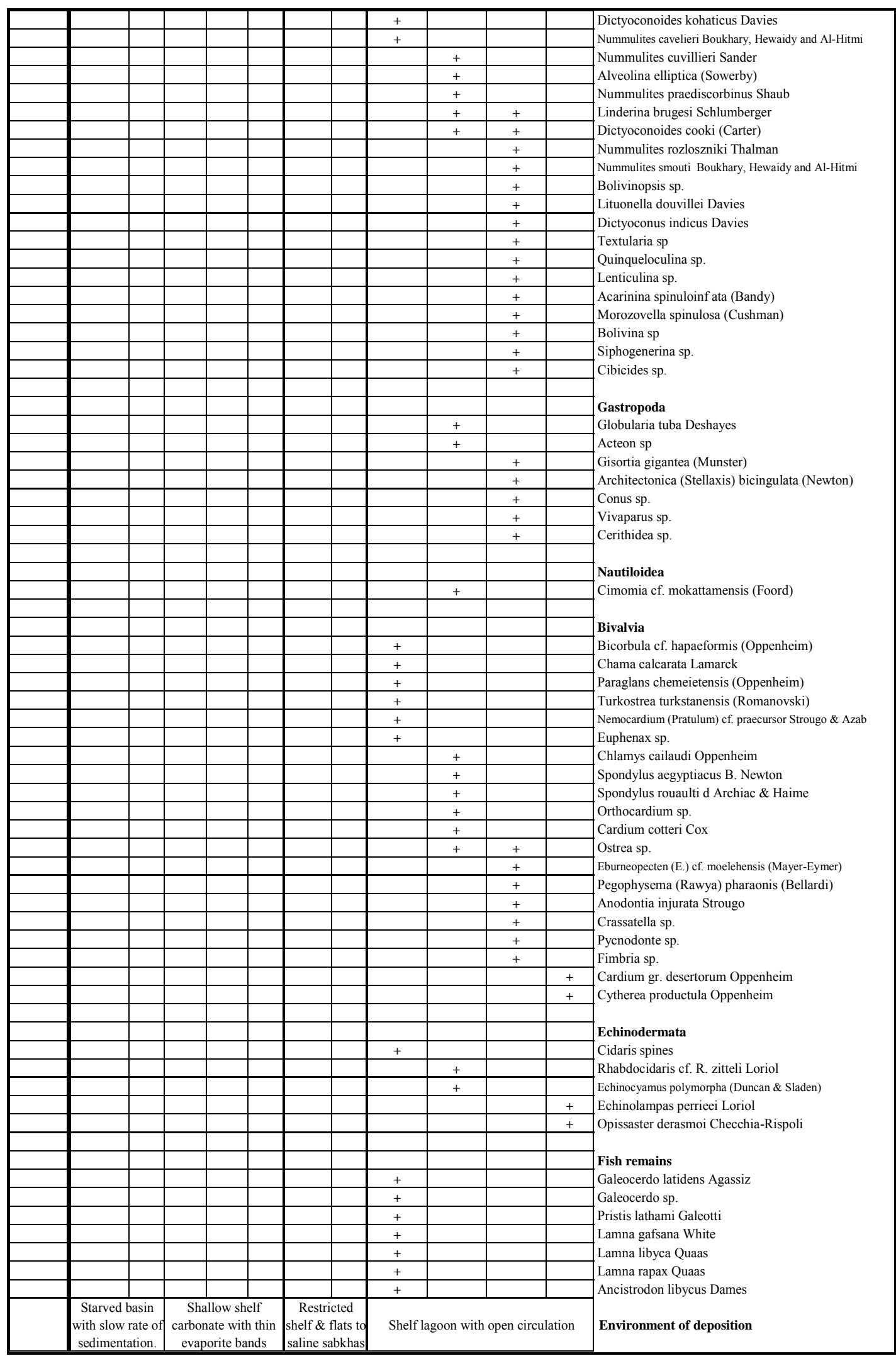

Fig. 7: The identified faunal elements in different Eocene units in Qatar and the interpreted depositional environments. 


\section{Sequence Stratigraphy of the Eocene rocks in Qatar Peninsula}

\section{CYCLICITY}

The Eocene rocks of Qatar are interpreted to be the product of two (sensu Vail et al., 1977) major "second order cycles", (Fig. 3). Stratigraphic evidence for these cycles occurs throughout the eastern Arabian Gulf. The first cycle was accumulated during the Early Eocene (Ypresian) formed of transgressive and high stand. The transgressive part of this cycle is composed of the lower two members of the Umm Er Radhuma Formation (A and B members). The dolomitic-carbonate sequence of the Umm Er Radhuma Formation and the evaporitic- carbonate sediments of the Rus Formation represent the highstand part of this cycle. The facies of this latter formation are interpreted to represent the final stage of a highstand systems tract (HST) and coincided with the forced progradational regression of a relative sea level fall that led to deposition of these restricted sediments at the end of this cycle. The top part of this cycle is represented by argillaceous facies with planktonic foraminifera denoting to deeper depositional conditions and represents the maximum flooding surface (MFS, Pg10) of that cycle.

The second cycle is of middle Eocene (Bartonian) age, and is composed of siliclastic- carbonate sediments of the Dammam Formation over the entire Arabian Shelf. This cycle is marked by a rapid and widespread sea level rise that led to deposition of a sequence started by the Midra Shale Member. The Midra Shale Member was accumulated in relatively deeper water as evidenced by the condensed section and abundant shark teeth. The Midra Shale is overlain by the other three members of the Dammam Formation; in ascending order, the Dukhan, Umm Bab and Abaruq members. These three members represent three small scale coarsening-upward, short-lived parasequence cycles.

Sharland et al. (2001), considered that the maximum flooding surface (MFS; Pg20) is located within the Midra Shale of the Dammam Formation. The basal contact of the lowermost argillaceous surface of the Midra Shale Member with the uppermost evaporitic facies of the underlying Rus Formation represents the final stage of the first highstand systems tract (HST) cycle (Jones and Racey, 1994). This assumption confirms the Bartonian age for the Dammam Formation and indicates an unconformity between the Rus Formation (Ypresian) and the Dammam Formation (Bartonian).

\section{SEQUENCE STRATIGRAPHY}

The sequence stratigraphic interpretation of the Eocene succession of Qatar is based on the observed facies characters, the biofacies, and the probable depositional settings present at this time in Qatar area and its relationship to the regional tectonic framework of the Arabian Peninsula. The local fossil assemblages provide high resolution biostratigraphic time control. This enabled their correlation with the Eocene successions of East Arabia extending our understanding of the evolution and the history of baselevel changes during the Eocene of Qatar Peninsula. It also explains the significant lateral changes of facies, their correlation and temporal relationships within the study area.

The Eocene succession in Arabia is included within the Arabian Plate Megasequence (AP10) of Sharland et al. (2001). The duration of this megasequence is 29 my, extending between 58 m.y. ago and 21 m.y. (Fig. 4). This relatively short lived megasequence includes two second order depositional sequences (sensu Vail et al., 1977). The older sequence is the Pg 10 of Sharland et al. (2001). It is of 9 m.y. duration and is represented by the Umm er Radhuma and Rus Formations. This depositional sequence is underlain by a maximum flooding surface (MFS) represented by the top of the Shammer Shale (member A) and B of the Umm Er Radhuma Formation.

The second and younger depositional sequence is Pg 20 of Sharland et al. (2001). It is of 4 m.y. duration and is represented by the Dammam Formation. The top of the Midra Shale represents a maximum flooding surface (MFS), (Fig. 8). 


\section{Plate 1. Photomicrographs of the different facies of the Dammam Formation.}

1- Medium rombic dolomite floating in micritic texture. Abaruq Member; Umm Bab section 2; X25.

2- Alveolina - Linderina in packstone facies with some fine rombic dolomites. Dukhan Member; Gebel Dukhan area; section 1; X100.

3- Ferruginous marl with shell remains. Mider Shale Member; Gebel Dukhan area; section 1; X25.

4- Horizontal lamination in clayey facies. Black lines are fractures. Midra shale; Gebel Dukhan area; section $1 ; \mathrm{X} 100$.

5- Cushmina sp. in marly limestone facies. The white is spar cement matrix. Abaruq Member; Umm Bab area; section 2; X25.

6- Nummulites smouti with echinoderm in pelloidal packstone. Note very fine dolomite rhombs. Umm Bab Member; Umm Bab area, section 2; X100.

Plate 1
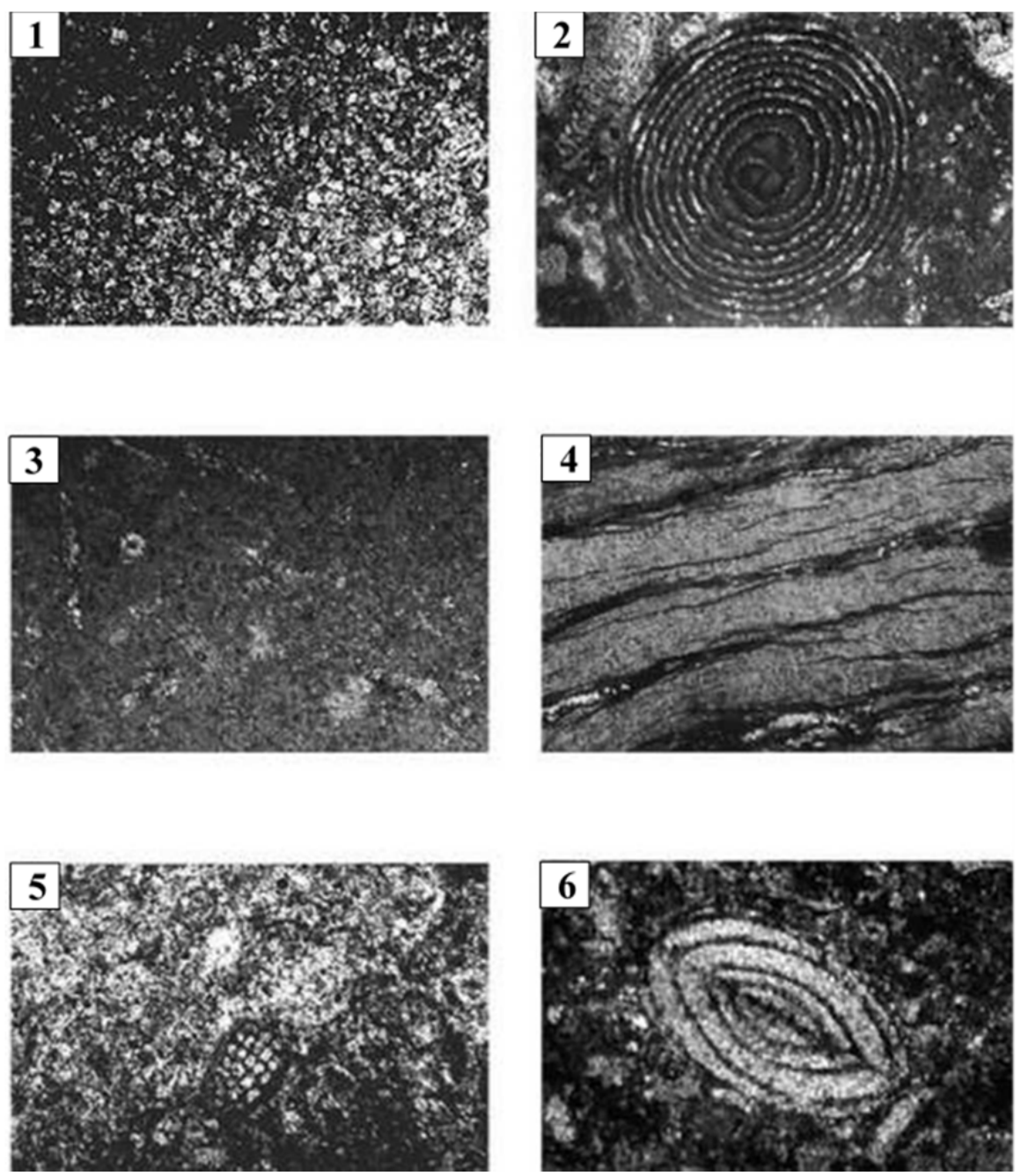
Sequence Stratigraphy of the Eocene rocks in Qatar Peninsula

\section{Plate 2. Photomicrographs of the different facies of the Dammam Formation.}

1- Shark tooth in Argillaceous limestone facies; Midra shale Member; Gebel Dukhan area; section 1; $\mathrm{X} 100$.

2- Lockartia hunti in wackestone facies. The white is spar cement; Dukhan Member; Gebel Dukhan area; section 1; X100.

3- Dolomitized packstone with Nummulite globus. Note microcrystalline calcite cement which is partly dolomitized; Umm Bab Member; Umm Bab area section 2; X25.

4- Operculina sp. with echinoid spines embedded in micrtic texture; Dukhan Member; Gebal Dukhan area; section $1 ; \mathrm{X} 40$.

5- Opertorbitolites-Nummulites in packstone facies. Dukhan Member; Gebal Dukhan area; section 1; X40.

6. Textularia sp. in compact wackestone facies. The white is spar cement. Umm Bab Member; Umm Bab area; section 2; X40.

Plate 2
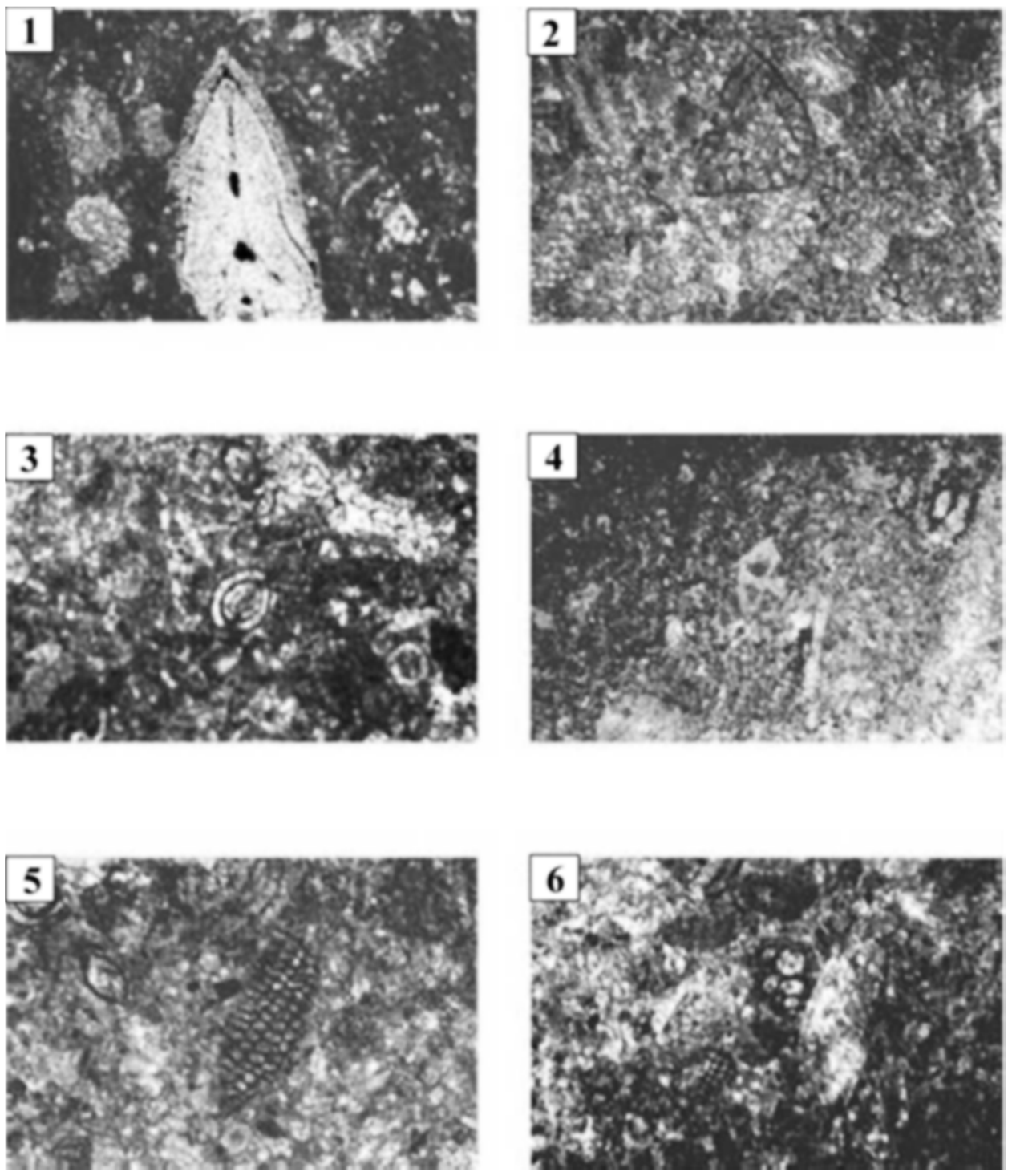


\section{Plate 3. Biofacies of the Dammam Formation.}

1- Nummulite bullatus in compact micritic texture. Dukhan Member; Gebal Dukhan area; section 1; X40.

2- Alveolina-Nummulites in wackestone facies. Dukhan Member; Gebal Dukhan area; section 1; X40.

3- Dictyoconus indicus in packstone facies. The white is spar calcite matrix; Dukhan Member; Gebal Dukhan area; section 1; X100.

4- Nummulites cf. smouti in wackestone facies. Dukhan Member; Gebal Dukhan area; section 1; X100.

5- Nummulites smouti in wackestone. Dukhan Member; Gebal Dukhan area; section 1; X100.

6- Linderina brugesi-Alveolina sp in pelloidal packstone. Note the highly Micritized Linderina. Dukhan Member; Gebal Dukhan area; section 1; X100.

\section{Plate 3}
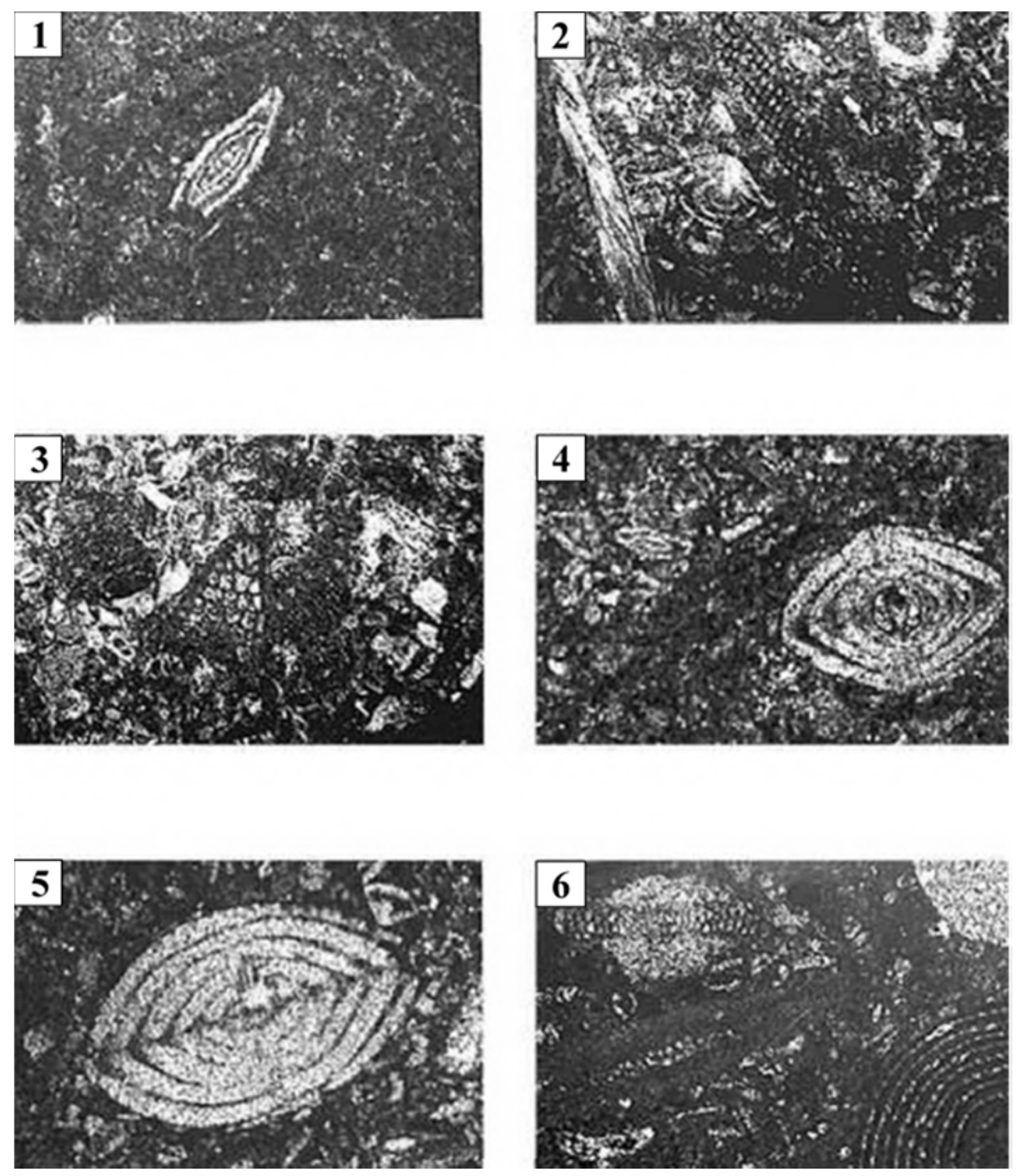


\section{Sequence Stratigraphy of the Eocene rocks in Qatar Peninsula}

\section{Plate 4. Representative fauna of Eocene of Qatar.}

1. Alveolina globosa Leymerie; transverse surface of broken specimen, Umm Er Radhuma Formation, Traina well, SE Qatar.

2. Acarinina sp.; dorsal view, Umm Er Radhuma Formation, Traina well, SE Qatar.

3. Daviesina langhami Smout, equatorial section, Umm Er Radhuma Formation, Traina well, SE Qatar.

4. Lockhartia haimei (Davies), dorsal view, Umm Er Radhuma Formation, Traina well, SW Qatar.

5. Rotalia trochidiformis (Lamarck), ventral view, Umm Er Radhuma Formation, Traina well, SW Qatar.

6. Sakesaria cotteri Davies, lateral view, Umm Er Radhuma Formation, Traina well, SW Qatar.

7. Nummulites cf. N. elegans (Sowerby), equatorial section, Umm Er Radhuma Formation, Traina well, SW Qatar.

8. Ranikothalia (?) sp. equatorial section, Umm Er Radhuma Formation, Traina well, SW Qatar.

9. Nummulitic wackestone with Nummulites and Lockhartia hunti Ovey, Dukhan Member, Dammam Formation, Qarn E1 Mazroua section, X25.

10. Architectonica (Stellaxis) bicingulata (Newton), Umm Bab Member, Dammam Formation, Umm Bab section, X1.

11. Gisortia gigantea (Munster), Umm Bab Member, Dammam Formation, G. Dukhan section, X1.

12. Cimomia cf. mokattamensis (Foord), Dukhan Member, Dammam Formation, Umm Bab section, X0.4.

13. Conus sp. Umm Bab Member, Dammam Formation, G. Dukhan section, X1.

14-15. Chlamys caillaudi Oppenheim, Dukhan Member, Dammam Formation, Umm Bab section, X1.

16. Turkostrea turkestanensis (Romanovski), Midra Shale Member, Dammam Formation, Umm Bab section, X0.9.

17. Rhabdocidaris cf. R. zitteli. Dukhan Member, Dammam Formation, Qarn El-Mazroua section, X1.

18-20. Echinolampas perrieri Loriol, Abaruq Member, Dammam Formation, Ras Abaruq section, X1.

\section{Plate 4}

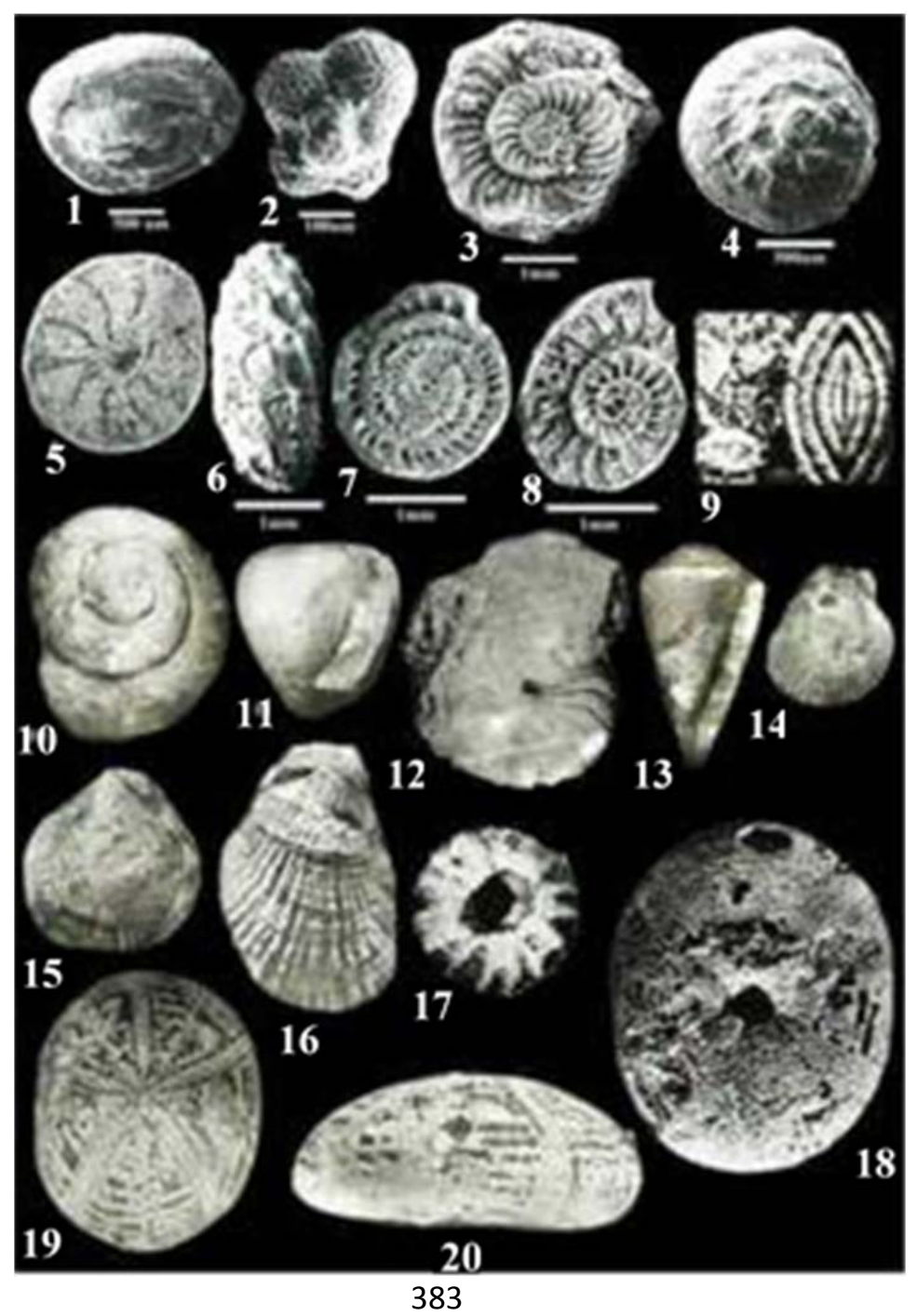




\section{Systems tracts and bounding surfaces}

Four systems tracts are distinguished (sensu Brown and Fisher, 1977 and Posamentier and Vail, 1988) in the Eocene succession of Qatar, i.e. two transgressive systems tracts (TST) and two late-rise (highstand) systems tracts (HST) respectively (Fig. 8). Each systems tract is bounded by sequence boundary (SB) or maximum flooding surface (MFS); each with a specific timing relative to the Haq \& Al-Qahtani (2005).

The subdivision of the Eocene succession of Qatar into systems tracts is based on the biofacies and the sedimentological characteristics of the facies associations described above, and on the nature of contacts that separate them.

The biofacies and lithofacies analysis of the Eocene rocks of Qatar show that the Eocene succession is composed of shallow marine carbonates and is subdivided into two depositional sequences whose architecture and spatio-temporal is shown in Fig. 8. There first order sequence boundaries bounded these two sequences and two maximum flooding surfaces topped the transgressive systems tracts of every sequence.

In chronological order, starting with the oldest, the sequence stratigraphic architecture of the Eocene stratigraphy of Qatar is:

\section{Sequence 1 (Pg 10)}

The lower depositional Eocene sequence (Pg 10) includes a transgressive systems tract capped by a maximum flooding surface (MFS) and overlain by a highstand systems tract. It is represented by the Umm er Radhuma Formation below and Rus Formation above (Fig. 8).

\section{The Transgressive Systems Tract 1}

This stage of base-level rise was represented by the dark shales of the Shammar Shale Member and the overlying B member of the Umm er Radhuma Formation. It needs 4 m.y. to be deposited, reflecting a condensation phase with the maximum flooding surface at top of this succession of strata. This succession was retrogradational at the base reaching to the maximum flooding phase at the top. The higher sea level of the maximum flood is characterized by a marked planktonic foraminiferal assemblage denoting an open marine phase at this time (Fig. 7).

\section{The Highstand Systems Tract 1}

The highstand systems tract of Pg 10 is represented by the upper major part of the Umm Er Radhuma Formation (members $\mathrm{C}$ and $\mathrm{E}$ ) and the overlying Rus Formation. It needs $5 \mathrm{~m} . \mathrm{y}$. to be deposited. It is dominated by shallow marine carbonates with an abundant larger foraminiferal assemblage. This succession is progradational in character in the lower part, changing to an aggradational succession at the top of the section when the deposition of the upper part of the Umm Er Radhuma Formation was accumulated and then ended with an evaporitic phase and sea level fall. This latter interval resulted in subareal erosion giving rise to the sequence boundary at the top of the Rus Formation (Fig. 8).

\section{Sequence 2 (Pg 20)}

This sequence is represented by the whole Dammam Formation. It is subdivided into transgressive systems tract at base and a highstand systems tract at top.

\section{The Transgressive Systems Tract 2}

This systems tract is represented by the Midra Shale Member of the Dammam Formation. It is composed mainly of shales with frequent occurrence of shark teeth. It needs $2 \mathrm{~m} . \mathrm{y}$. to be deposited. This unit is capped by a maximum flooding surface (MFS2). 


\section{Sequence Stratigraphy of the Eocene rocks in Qatar Peninsula}

\section{The Highstand Systems Tract 2}

This systems tract is represented by the Dukhan, Umm Bab and Abaruq members of the Dammam Formation which are composed mainly of a shallow marine carbonates with larger foraminiferal faunal assemblage and frequent megafossil content. It needs $2 \mathrm{~m} . \mathrm{y}$. to be deposited. It is a progradational in character in its lower part, changing to aggradational with exposure reaching to maximum sea level fall and forming a sequence boundary (Fig. 6).

Fig. 8: The Eocene sequence stratigraphic

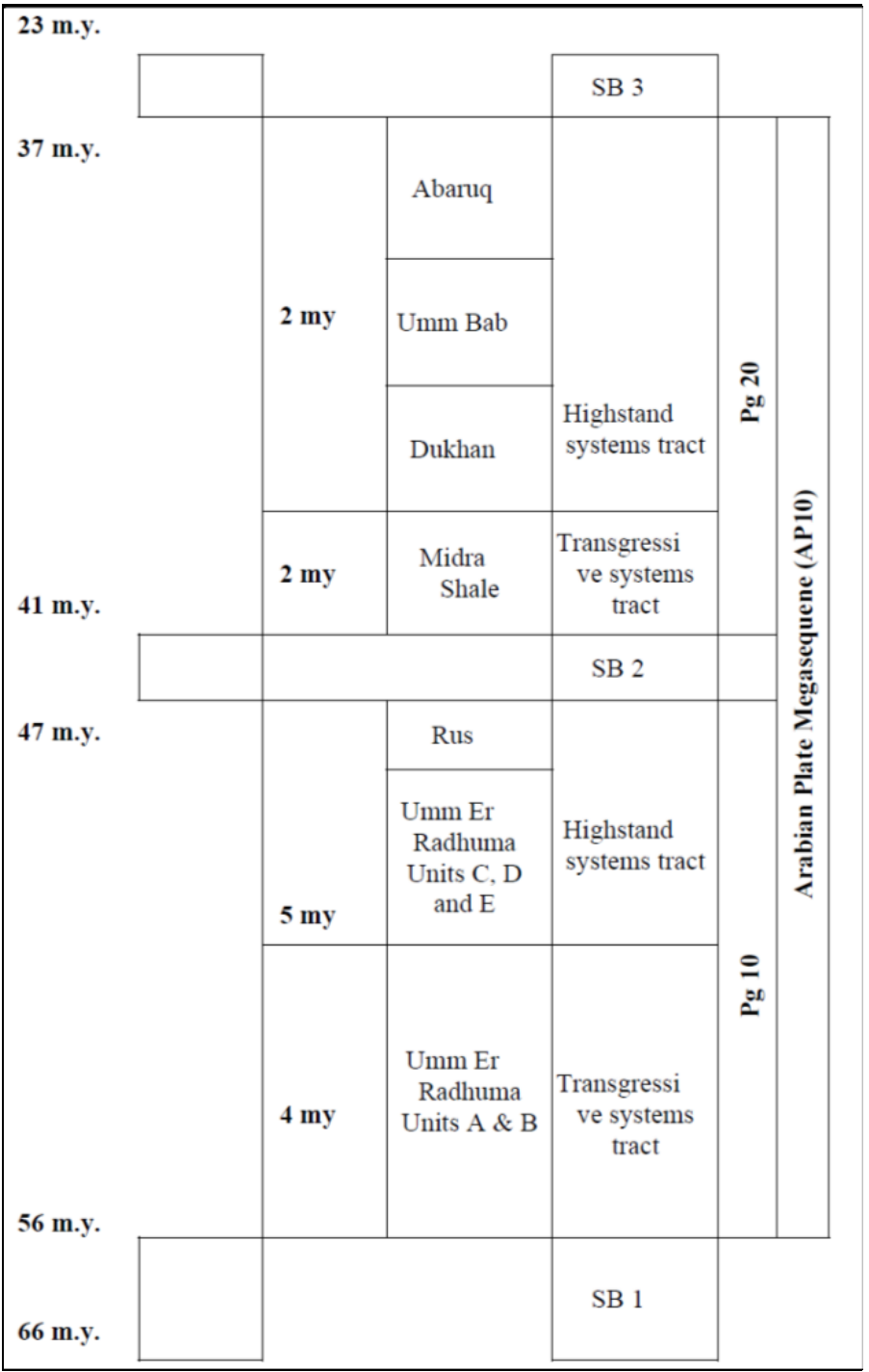
classification and sequence boundaries in Qatar Peninsula.

\section{CONCLUSIONS}

The Eocene sequences of Qatar have been subdivided into the Umm er Radhuma, Rus and Dammam formations from base upwards. The Umm er Radhuma Formation consists of a succession of shaley argillaceous limestone at the base, which gradually changes to foraminiferal argillaceous limestone in the middle and ends with fossiliferous gypsiferous limestone. The Umm Er Radhuma Formation is subdivided into five characteristically lithologic units throughout Qatar. Based on pelagic foraminifera, the formation is assigned to the Lower Eocene (Ypresian). The Rus Formation consists of a succession of gypsiferous dolomitic limestone in its lower part (Traina Member) and a chalky limestone in its upper part (Al-Khor Member). The Rus Formation is assigned to the Lower Eocene Ypresian. The Dammam Formation is dominated by a succession of argillaceous limestone in its lower part and dolomitic limestone in its upper part. It is assigned to the Middle Eocene (Bartonian age). 


\section{Al-Saad, H. A. and Hewaidy, A. A.}

This Eocene succession has been attributed to the Arabian Plate megasequence AP10 and was subdivided into two second order sequences (Pg 10 and Pg 20) ) by Sharland et al. (2001) and is followed here. Studies of the lithofacies and biofacies of this megasequence in Qatar have enabled the identification and interpretation of the depositional settings and faunal elements of the different Eocene units. The lower $\mathrm{Pg} 10$ sequence is represented by the Umm Er Radhuma and Rus formations, and is subdivided into a lower transgressive and an upper highstand systems tract, while the upper Pg 20 sequence is represented by the Dammam Formation, and is subdivided into a transgressive and a highstand systems tract. These two sequences are bounded by three major sequence boundaries.

\section{ACKNOWLEDGMENTS}

The authors would like to thank Professors Fadhil Sadooni (Qatar University) and Christopher George St. Clement Kendall (University of South Carolina) for their critical review of the manuscript.

\section{REFERENCES}

Abu-Zeid, M. M. (1991): Lithostratigraphy and framework of sedimentation of the subsurface Paleogene succession in northern Qatar, Arabian Gulf. Neues Jahrbuch für Geologie und Paläontologie, Abhandlungen 4: 191-204.

Abu-Zeid M. M. and Boukhary M. A. (1984): Stratigraphy, facies and environment of sedimentation of the Eocene rocks in the Fhaihil (Gebel Dukhan), Qatar, Arabian Gulf. Revue De Paleobiologie 3: 159173.

Al-Hajari, S. (1987): The sedimentology of the Lower Eocene Rus Formation and its relationship to the ground water of the State of Qatar, the Arabian Gulf. Unpublished M. Sc. Thesis, University of South Carolina, 121p.

Al-Saad, H. A. (2003): Facies analysis, cyclic sedimentation and paleoenvironment of the Middle Eocene Rus Formation of Qatar and adjoining areas. Carbonates and Evaporites, 18: 41-50.

Al-Saad, H. A., (2005): Lithostratigraphy of the Middle Eocene Dammam Formation of Qatar, Arabian Gulf: effects of sea-level fluctuation along a tidal environment. J. Asian Earth Sci., 25: 781-789.

Alsharhan, A. and Nairn, A. (1995): Tertiary of the Arabian Gulf. Sedimentology and hydrocarbon potential. Paleogeography, Paleoclimatolog and Paleoecology, 114: 369-384.

Alsharhan, A. and Nairn, A. (1997): Sedimentary Basins and Petroleum Geology of the Middle East. Elsevier, Netherlands, $811 \mathrm{p}$.

Blondeau, A. and Cavelier, C. (1972): Le Teriaire de la presquile du Qatar (Golfe Arabique). Donnees nouvelles fournies par les grands Foraminiferes de 1'Eocene moyen. Bull. Soc. Geology, France, 7: 165-170.

Boukhary, M. A. (1985): Paleontological studies on the Eocene succession in western Qatar, Arabian Gulf. Revue De Paleobiologie, 4: 183-202.

Boukhary, M. A. and Alsharhan, A.S. (1998): A stratigraphic lacuna within the Eocene of Qatar: an example of the interior platform of the Arabian Peninsula. Revue de Paleobiologie, Geneve, 17-1, 49-68.

Boukhary, M., Hewaidy, A., Luterbacher, H. P., Bassiouni, M. and Al-Hitmi, H. (2011): Foraminifera and ostracodes of Early Eocene Umm Er radhuma Formation, Dukhan Oil Field, Qatar. Micropaleontology, 57: 37-60.

Bramkamp, R. A. (1946): Unpublished report. In Cavelier, C. (1970), Geological description of the Qatar Peninsula (Arabian Gulf). Qatar Department of Petroleum Affairs, 39 p.

Brown, L. F. Jr. and Fisher, W. L. (1977): Seismic stratigraphic interpretation of depositional systems: examples from Brazilian rift and pull apart basins. In Payton, C. E. (Ed.), Seismic Stratigraphy Applications to Hydrocarbon Exploration. American Association of Petroleum Geologists, Memoir 26: 213-248.

Casier, E. (1971): Sur un material Ichthylologique des "Midra (and Saila) Shales" du Qatar (Golfe Persique). Bulletin of Royal Institution of Natural Science, 47: 1-9.

Cavelier, C. (1970): Geological description of the Qatar Peninsula (Arabian Gulf). Qatar Department of Petroleum Affairs, $39 \mathrm{p}$. 


\section{Sequence Stratigraphy of the Eocene rocks in Qatar Peninsula}

Dill, H., Nasir, S. and Al-Saad, H. (2003): Lithological and structural evolution of the Northern sector of Dukhan anticline, Qatar, during the early Tertiary: with special reference to sequence stratigraphic bounding surfaces. Geoarabia, 8: 1-26.

El-Khayal, A. A. (1974): Foraminiferal biostratigraphy of the Umm er Radhuma Formation (Paleocenelower Eocene) of Eastern Saudi Arabia. Bulletin of Faculty of Science, Riyadh University, 6: 195-214.

Haq, B. and Al-Qahtani, A. (2005): Phanerozoic Cycles of Sea-Level Change on the Arabian Platform. GeoArabia, 10: 127-160.

Hasson, P. F. (1985): New observations on the biostratigraphy of the Saudi Arabian Umm er Radhuma Formation (Paleogene) and its correlation with neighboring regions. Micropaleontology, 31: 35-364.

Hewaidy, A. (1994): Biostratigraphy of the Umm er Radhuma Formation in southeast Qatar, Arabian Gulf. Neues Jahrbuch für Geologie und Paläontologie, Abhandlungen, 193:145-164.

Hewaidy, A. and Al-Hitmi, H. (1994): Cretaceous-Early Eocene biostratigraphy of the Dukhan Oil Field, west Qatar, Arabian Gulf. Ain Shams Earth Sci. Ser., 8: 1-24.

Hewaidy, A. and Al-Hitmi, H. (1999): Paleoecology of the Cretaceous - Early Tertiary sequence in the Dukhan Oil Field, west Qatar, Arabian Gulf. Inter.Conf. Geol. the Arab World (GAW 4), Cairo Univ., Egypt, 1010-1023.

Hewaidy, A. and Al-Saad, H. (1993): Surface Eocene stratigraphy of Qatar Peninsula. Al-Azhar Bull. Sci., 4: 165-194.

Neal, J. and Abreu, V. (2009): Sequence Stratigraphy Hierarchy and the Accommodation Succession Method. Geology, 37: 779-782.

Posamentier, H. and Vail, P. R. (1988): Eustatic controls on clastic deposition. II. sequence and systems tract models. In Wilgus, C. K., Hastings, B.S., Kendall, C.G.C.,

Posamentier, H., Ross, C. A. and Vanwagoner, J. C. (Eds.) Sea Level Changes-An Integrated Approach. SEPM Spec. Publ. 4: 125-154.

Powers, R. W. (1968): Saudi Arabia. Lexique Stratigraphique International Asie.Centre Natural Res., Paris, $11(10 \mathrm{~b} 1), 177 \mathrm{p}$.

Powers, R. W., Ramirez, L., Redmond, C. and Elberg, Jr. E. (1966): Geology of the Arabian Peninsula: Sedimentary Geology of Saudi Arabia, US Geological Survey Professional Papers, 560-D, 147p.

Roman, J. (1976): Echinides Eocenes et Miocenes du Qatar (Golfe Persique). Ann. De Paleobiologie (Invertebraes), 62: 49-85.

Sander, N. (1952): La stratigraphy de 1 'Eocene le long du rivage occidental du Golfe Persique. Univ. Paris, Unpublished Thesis, 257p.

Sharland, P., Archer, R., Casey, D., Davies, R., Hall, S., Heward, A., Horbury, A. and Simmons, M. (2001): Sequence Stratigraphy of the Arabian Plate. In Husseini (Ed.), GeoArabia Spec. Publ. 2.

Smout, A. H. (1954): Lower Tertiary Foraminifera of the Qatar Peninsula. British Museum. (Natural History), 90p.

Steineke, M. and Bramkamp, R.A. (1952): Mesozoic rocks of eastern Saudi Arabia (abs.). American Association of Petroleum Geologists, 36: $909 \mathrm{p}$.

Sugden, W. (1962): Structural analysis and geometrical prediction for change form with Depth of some Arabian plain-type folds. American Association of Petroleum Geologists 46: 2213- 2228.

Sugden, W. and Standring, A. (1975): Qatar Peninsula. Lexique stratigraphique Internationale, 3: 1-88.

Tleel, J. (1973): Surface geology of Dammam Dome, Eastern Province, Saudi Arabia. American Association of Petroleum Geologists, 57: 558-576.

Vail, P. R., Mitchum, Jnr.R. M., Todd, R. G., Thompson, J. S., Sangree, J., Bubb, J. and Hatelid, W. (1977): Seismic stratigraphy and global change of sea level. In Mitchum Jnr. R. M., Vail, P. R. and Sangree, J. (Eds). American Association of Petroleum Geologists, Memoir 26: 49-212.

Willis, R. (1967): Geology of Arabian Peninsula, Bahrain. US Geol. Surv. Prof. Papers, 560-E, 4p. 
Al-Saad, H. A. and Hewaidy, A. A.

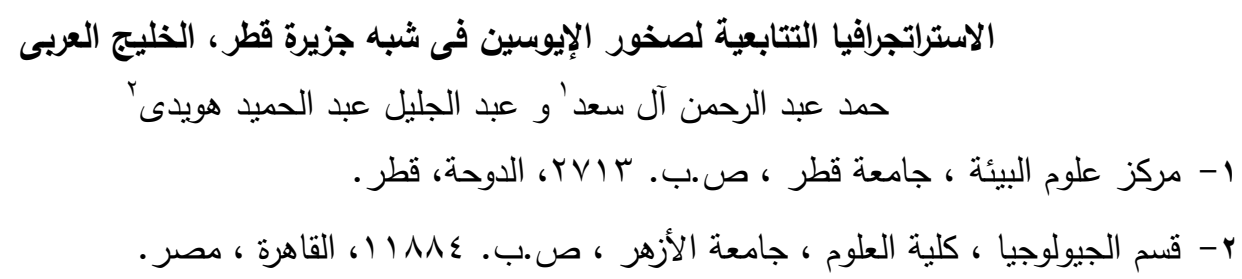

\section{الخلاصة}

ينقسم تتابع الإيوسين الرسوبى فى قطر إلى منكونات أم الرضومة والرس والدمام من أسفل لأعلى والتى يسفلها متكون السمسمة التابع للمسترختى ويعلوها متكون الدام التابع للميوسين ـ ويمنل هذا التتابع جزءا من تتابع لوح شبه الجزيرة العربية

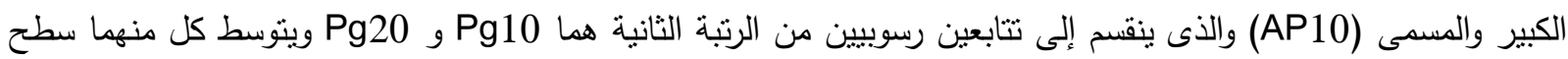
غر أقصى maximum flooding surface. وقد أدت دراسة خصائص السحن الصخرية والحيوية لتتابع الإيوسين فى قطر لتهر للتعرف على المحتوى الحفرى والصخرى وتفسير بيئة تكوين كل متكونات ذللك التتابع ووضع تصور لتغير منسوب سطح البحر

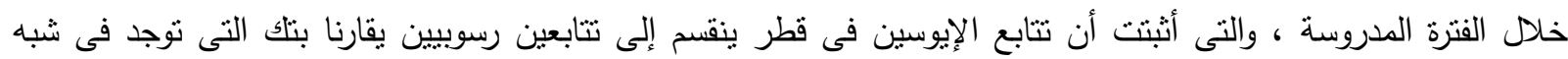

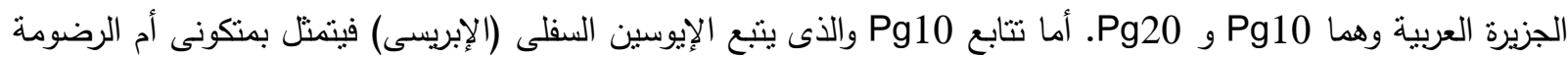
والرس وينقسم إلى نظامى مسلك systems tracts هما نظام مسلك تجاوز بحرى transgressive systems tract لأسفل ويشمل عضوى أ و ب الممنلين للجزء السفلى من متكون أم الرضومة، ويحد نظام المسلك هذا من أسفل سطح عدم توافق يمثل

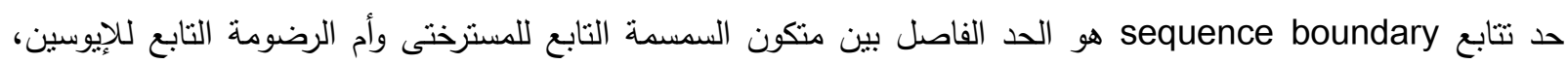
وينتهى نظام المسلك هذا بسطح غمر أقصى maximum flooding surface ، ثم يعلوه نظام مسلك سطح بحر مرتفع

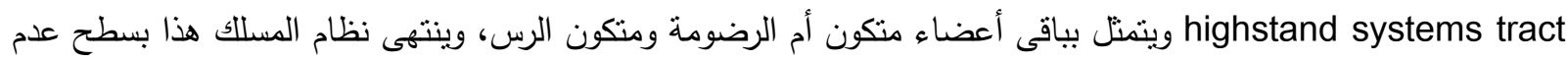

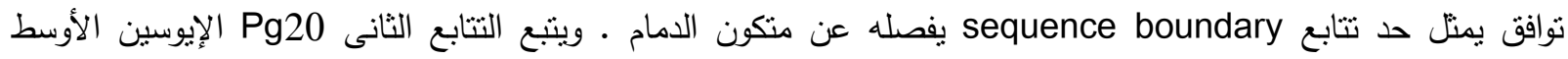

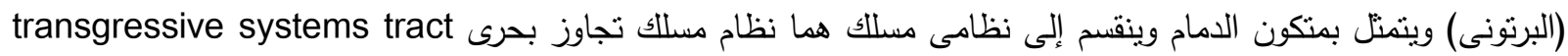

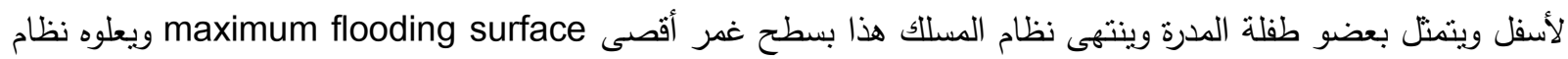
مسلك سطح بحر مرتفع highstand systems tract ويتمنل بأعضاء الدمام وأم باب والأبروق وينتهى بسطح عدم نوافق يمنل حد تتابع boundary sequence يفصله عن متكون الدام التابع للميوسين. 